REFERENCES

Lehmann-Maquenne, in G. Klein (1932). Handbuch der Pflanzenanalyse, Vol. 2, p. 786 . Wien: Julius Springer.

Pope, C. G. \& Stevens, M. F. (1939). Biochem. F. 33, 1070.

Schlottke, E. (1939). S.B. naturf. Ges. Rostock, 7, 27. See also Chem. Abstr. (1942). 36, 6673.

Sørensen, S. P. L. (1907). Biochem. Z. 7, 45.

Vonk, H. J. (1927). Z. vergl. Physiol. 5, 445.

Wundsch, W. (1927). Die Arbeitsmethoden der Fischereibiologie. Berlin-Wien: Urban und Schwarzenberg.

\title{
Effect of Feeding Aureomycin to Calves upon the Establishment of their Normal Rumen Microflora and Microfauna
}

\author{
By S. O. MANN, FRANCES M. MASSON AND A. E. OXFORD \\ Rowett Research Institute, Bucksburn, Aberdeenshire
}

(Received I7 December 1953)

American experience (summarized by Knodt, I953) is overwhelmingly in favour of the view that daily feeding of small amounts of aureomycin to calves, from about the Ioth to the I2oth day of age, markedly increases their appetite, growth rate and general well-being. It is during this period of its life that the calf gradually becomes a multi-stomached animal with development of a dense and characteristic population of living micro-organisms in its rumen, reticulum and omasum. It is known that the antibiotic in question, aureomycin, has certain well-marked properties which differentiate it from, for example, penicillin and streptomycin, namely:

(a) Wide bacteriostatic (not bactericidal) powers, inhibiting nearly all bacteria, Gram positive as well as Gram negative, although, as usual, cocci are the most sensitive bacteria (Paine, Collins \& Finland, I948), the few exceptions to this rule being aerobes such as Pseudomonas and Proteus which normally do not flourish in an anaerobic environment like the rumen.

(b) No marked power of inducing the formation of antibiotic-resistant strains of bacteria; in this respect it is unlike streptomycin.

(c) Inability to induce the formation of an 'aureomycinase' in any bacterial species.

(d) Maximum chemical stability well on the acid side of neutrality (Schneierson \& Toharsky, 1949); in this respect as in the last it is unlike penicillin.

(e) Power of inhibiting protein synthesis by bacteria at an extremely small concentration without inhibiting the processes of fermentation (Gale \& Folkes, 1953).

It might therefore be expected that the feeding of aureomycin from an early stage would exert some characteristic effect upon the establishment of the normal adult microbial population of the rumen. This effect might be either to delay its full appearance, or to change its composition both as regards density of population and the relative numbers of the different kinds of bacteria represented. This argument supposes, however, that a sufficiently high concentration of aureomycin is built up 
and maintained in the rumen for many weeks. The study here described had therefore two aims in view : (I) to follow the changes in concentration of aureomycin in the rumen, omasum and abomasum with increasing age of the animal, given aureomycin daily in a manner and at a level typical of American practice, and (2) to compare the respective rumen microflora and microfauna of several sets of aureomycin-fed and control calves of the same breed and age, from a few weeks of age onwards, all calves being reared in the same way by following good standard practice.

\section{EXPERIMENTAL}

Plan of experiment. Since this experiment was merely exploratory, only three sets of calves were used. They were killed at about 5,8 and $12 \frac{1}{2}$ weeks of age respectively. Each set comprised two aureomycin-fed calves and one control. In addition the paunch and abomasum of a ro-day-old calf (calf o) were examined in detail. This calf was representative of the others before feeding of aureomycin began.

Rearing of calves. Ten Ayrshire bull calves, all born in May 1953, were purchased from nearby farms when about I week old. Subsequent rearing was as follows:

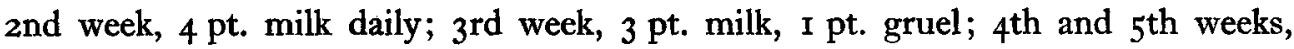
2 pt. each of milk and gruel; 6th week, I pt. milk, 3 pt. gruel; after the 6th week, gruel but no milk. From the $3^{\text {rd }}$ week onwards, linseed meal ( $\frac{1}{2} \mathrm{lb}$. thrice a day), hay and oats were given, together with grass $a d l i b$. after the 6 th week. Calves were weighed weekly and housed all the time indoors.

Administration of aureomycin. The pure hydrochloride ( $40 \mathrm{mg}$ ) dissolved in half the daily portion of gruel ( $0.5^{-1} \cdot 5 \mathrm{pt}$. according to age of calf) was given at $7 \mathrm{a.m}$. by bucket usually from the I2th day of age onwards (see Table I). After the 6th week, the remaining aureomycin-fed calves received $60 \mathrm{mg} /$ day.

Examination of contents of paunch. Immediately after slaughter (always at io a.m.) the rumen-reticulum, omasum and abomasum were separately tied off at each end with double ligatures between compartments, removed to the laboratory as quickly as possible while still warm and the contents of each transferred to clean tared enamel receptacles; the contents were then thoroughly mixed and weighed. Small samples from each receptacle were transferred to sterile tared plugged flasks which were immediately reweighed and placed in a $37^{\circ}$ incubator until all was ready for the bacteriological and protozoological examination. This procedure was always carried out within $\mathrm{I}-2 \mathrm{~h}$. Portions of the remainder of the ingesta were then strained through muslin and the $\mathrm{pH}$ determined by glass electrode without delay. The $\mathrm{pH}$ could not always be determined with omasum contents, which were often too thick to be strained even if the maximum power of squeezing by hand was exerted.

Aureomycin was determined in whole rumen, omasum, abomasum and in one instance caecum contents by the pad-plate method of assay (Grady \& Williams, I953), which is sensitive to about $0 . \mathrm{I} \mu \mathrm{g} / \mathrm{g}$. The applicability of the method was first tested on the gruel containing dissolved aureomycin as fed to the calves (found, $15 \mu \mathrm{g} / \mathrm{g}$; expected, $16 \mu \mathrm{g} / \mathrm{g}$ ). The recovery of aureomycin was also almost quantitative in sheep's rumen liquor to which it had been added.

Bacteriological examination. Smears were first made directly from rumen or 
abomasum contents, fixed by heat and stained by Gram's method. Then the muslinstrained ingesta were spun down in stages at $3350 \mathrm{~g}$ in a small angle-head centrifuge and portions of the successive deposits emulsified in water and examined both in wet preparations after addition of Lugol's iodine (for vegetable starch grains and attached bacteria) and by Gram staining after heat fixation.

Since aureomycin is known to inhibit nearly all bacterial species at concentrations below $20 \mu \mathrm{g} / \mathrm{ml}$., it was considered legitimate to concentrate upon one group of authentic rumen bacteria, namely the facultatively anaerobic and amylolytic streptococci which appear to be common to both ox and sheep rumens (Hungate, Dougherty, Bryant \& Cello, 1952; MacPherson, 1953; Mann, Masson \& Oxford, 1954), viable counts of which are easily performed using cleared rumen liquor agar deeps containing cellobiose (Heald, Krogh, Mann, Appleby, Masson \& Oxford, 1953). Streptococcus faecalis also ferments cellobiose but, since unlike the rumen amylolytic streptococci it usually ferments mannitol, there is in rumen contents from the adult animal always a big discrepancy between counts with cellobiose and counts with mannitol as the carbohydrate source (Heald et al. 1953). The latter counts also include coliform bacteria. Attempts were made by Miss E. Mackay of this laboratory to isolate cultures of anaerobic Gram-negative cocci (usually common in the rumen and according to Paine et al. (1948) the most sensitive bacteria of all to aureomycin), but these experiments and also the detailed bacteriological examination of the rumen streptococci and other Gram-positive bacteria will be dealt with in another paper. The numerical values of the viable counts only are considered here.

Protozoological examination for characteristic living rumen ciliates. This was done by mere inspection under the low power of the microscope of muslin-strained rumen contents which had not been allowed to cool below $30^{\circ}$. A wet preparation was made with very dilute Lugol's iodine to determine whether starch-ingesting ciliates were present (cf. Sugden \& Oxford, I952).

\section{RESULTS}

Growth rates of aureomycin-fed and control calves. Table I shows that on the whole the aureomycin-fed calves perhaps grew a little faster than the controls but, since only a small group of animals was used, the results are hardly significant and may be regarded only as not contradicting American experience.

Weights and $\mathrm{pH}$ values of various ingesta. The results are given in Table 2 . It is felt that the results for the second set of calves $\left(2 \mathrm{~A}, 2 \mathrm{~A}^{\prime}\right.$ and $2 \mathrm{C}$ ) provide the most significant indication of the effect of aureomycin. The control calf $(2 \mathrm{C})$, the oldest of the three, had a lighter and more acid rumen than the others. The aureomycin-fed calves always possessed drier-looking rumen contents than the corresponding controls.

Aureomycin concentrations in various parts of the digestive tract. Table 3 shows that the antibiotic was usually detectable with certainty only in the abomasum.

Rumen bacterial counts. The second and third sets of calves (the older groups), both aureomycin-fed and controls, had rumens in which all the obvious signs of bacterial activity were observed, e.g. starch grains sheathed in bacteria and considerable gas production on further incubation at $39^{\circ}$. The stained smears also showed few, if any, 
Table I. Growth of aureomycin-fed calves $\left(A\right.$ and $\left.A^{\prime}\right)$ and control calves $(C)$

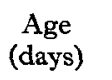

I5

18

2 I

24

27

30

33

36

39

42

45

48

51

57

6

63

66
69

72

75

78

84

87

90

93
96

99

I02

I05

Weight of calf (lb.)

\begin{tabular}{|c|c|c|c|c|c|c|c|c|}
\hline IA & IA & IC & $2 \mathrm{~A}$ & $2 \mathrm{~A}^{\prime}$ & ${ }_{2} \mathrm{C}$ & 3A & $3 \mathrm{~A}^{\prime}$ & ${ }_{3} \mathrm{C}$ \\
\hline- & - & 68 & 83 & 89 & - & - & - & 85 \\
\hline $73, a$ & - & - & $a$ & $a$ & - & - & $a$ & - \\
\hline 0 & $77, a$ & 80 & $\bar{a}$ & - & 76 & 一 & - & $\overline{00}$ \\
\hline 82 & $\overline{82}$ & - & 87 & 93 & - & - & 85 & 88 \\
\hline- & - & $8 \mathrm{I}$ & 97 & 98 & 85 & - & 94 & 97 \\
\hline 84 & 94 & - & 2 & - & - & $a$ & - & - \\
\hline 一 & - & 83 & - & - & 84 & - & - & 106 \\
\hline 96 & - & 85 & I06 & IOI & - & 87 & 103 & 一 \\
\hline- & 108 & - & - & - & 93 & 一 & - & - \\
\hline 一 & - & 一 & I 10 & I I I & 一 & IOI & 120 & 116 \\
\hline- & 123 & - & - & - & - & - & - & - \\
\hline 一 & - & - & 128 & 125 & 106 & II7 & I3I & 135 \\
\hline- & - & - & - & - & - & 一 & - & - \\
\hline 一 & 一 & - & I38 & 135 & II 3 & - & - & - \\
\hline- & 一 & - & - & - & - & I28 & 142 & 147 \\
\hline 一 & - & 一 & 一 & r34 & 125 & 一 & - & 一 \\
\hline - & - & - & - & - & 127 & 140 & 153 & 157 \\
\hline- & - & 一 & 一 & 一 & - & 一 & - & - \\
\hline 一 & - & - & 一 & - & - & I56 & 167 & 168 \\
\hline - & - & - & - & - & - & - & 一 & - \\
\hline - & - & — & - & 一 & - & - & - & - \\
\hline - & - & - & 一 & - & - & I 73 & 177 & 172 \\
\hline - & - & - & 一 & - & - & 二 & - & - \\
\hline- & - & - & - & - & - & I 89 & 182 & 180 \\
\hline- & - & 一 & - & - & 一 & - & - & - \\
\hline - & 一 & - & - & - & - & 208 & 200 & 185 \\
\hline - & - & - & - & - & 一 & - & - & 一 \\
\hline 一 & - & - & 一 & 一 & - & - & 207 & - \\
\hline- & - & 一 & - & - & 一 & 217 & 214 & - \\
\hline - & - & 一 & - & - & - & - & 一 & - \\
\hline - & - & - & - & 一 & - & 227 & - & - \\
\hline- & - & 一 & - & - & - & 237 & - & - \\
\hline
\end{tabular}

Table 2. Weight and $\mathrm{pH}$ values of rumen, omasum and abomasum contents of aureomycin-fed calves ( $A$ and $A^{\prime}$ ) and control calves $(C)$

\begin{tabular}{|c|c|c|c|c|c|c|c|c|}
\hline \multirow[b]{2}{*}{$\begin{array}{c}\text { Calf } \\
\text { no. }\end{array}$} & \multirow[b]{2}{*}{$\begin{array}{c}\text { Age } \\
\text { (days) }\end{array}$} & \multirow{2}{*}{$\begin{array}{l}\text { Period of } \\
\text { aureomycin- } \\
\text { feeding } \\
\text { (days) }\end{array}$} & \multicolumn{2}{|c|}{ Rumen contents } & \multicolumn{2}{|c|}{ Omasum contents } & \multicolumn{2}{|c|}{ Abomasum content } \\
\hline & & & $\begin{array}{c}\text { Weight } \\
(\mathrm{kg})\end{array}$ & $\mathrm{pH}$ & $\begin{array}{c}\text { Weight } \\
\text { (kg) }\end{array}$ & $\mathrm{pH}$ & $\begin{array}{c}\text { Weight } \\
\text { (kg) }\end{array}$ & $\mathrm{pH}$ \\
\hline o* & Io & 0 & 0.3 & $6 \cdot I$ & very small & - & 0.19 & $4 \cdot I$ \\
\hline IA & 33 & 22 & $6 \cdot 1$ & $5 \cdot 7$ & 0.15 & 一 & $I \cdot 33$ & $4 \cdot 75$ \\
\hline $\mathbf{r A}^{\prime}$ & 43 & 27 & $3 \cdot 72$ & $5 \cdot 5$ & 0.13 & - & $\mathrm{I} \cdot 97$ & 3.45 \\
\hline $\mathrm{rC}$ & 32 & 0 & $2 \cdot 17$ & $5 \cdot 0$ & 0.04 & - & 0.75 & $2 \cdot 85$ \\
\hline $2 \mathrm{~A}$ & 54 & 43 & $7 \cdot 32$ & 6.0 & 0.07 & - & $I \cdot 19$ & $3 \cdot 2$ \\
\hline $2 \mathrm{~A}^{\prime}$ & 59 & 48 & $7 \cdot 43$ & $6 \cdot 4$ & 0.11 & - & $1 \cdot 53$ & $2 \cdot 6$ \\
\hline $2 \mathrm{C}$ & 60 & 0 & $5 \cdot 8$ & $5 \cdot 7$ & 0.06 & - & $x \cdot 72$ & $3 \cdot 1$ \\
\hline $3 \mathrm{~A}$ & 105 & 77 & $20 \cdot 35$ & 6.8 & 0.87 & $6 \cdot 9$ & $I \cdot 45$ & $2 \cdot 75$ \\
\hline $3 \mathrm{~A}^{\prime}$ & 96 & 83 & $15 \cdot 38$ & $6 \cdot 1$ & 0.64 & - & 0.99 & 3.7 \\
\hline $3 \mathrm{C}$ & 86 & 0 & 9.5 & 6.0 & 0.42 & 一 & $1 \cdot 3^{8}$ & $2 \cdot 4$ \\
\hline
\end{tabular}

The caecum contents of calf $2 \mathrm{~A}$ weighed $0.36 \mathrm{~kg}$ and had a $\mathrm{pH}$ of 7.5 .

* See p. 247 . 
Table 3. Amount of aureomycin in the ingesta of the omasum and abomasum of aureomycin-fed calves

\begin{tabular}{|c|c|c|}
\hline Calf no. & Organ & $\begin{array}{c}\text { Concentration } \\
\text { of aureomycin } \\
(\mu \mathrm{g} / \mathrm{g})\end{array}$ \\
\hline $\mathbf{I} \mathbf{A}^{\prime}$ & Abomasum & $I \cdot 7$ \\
\hline $\mathbf{I} A^{\prime}$ & Omasum & $\circ$ \\
\hline $\begin{array}{l}2 \mathrm{~A} \\
2 \mathrm{~A}^{\prime}\end{array}$ & $\begin{array}{l}\text { Abomasum } \\
\text { Abomasum }\end{array}$ & $\begin{array}{l}5 \cdot 6 \\
3 \cdot 4\end{array}$ \\
\hline $\begin{array}{l}2 \mathrm{~A} \\
2 \mathrm{~A}^{\prime}\end{array}$ & $\begin{array}{l}\text { Omasum } \\
\text { Omasum }\end{array}$ & $\begin{array}{l}0 \\
0.5\end{array}$ \\
\hline $\begin{array}{l}3 \mathrm{~A} \\
3 \mathrm{~A}^{\prime}\end{array}$ & $\begin{array}{l}\text { Abomasum } \\
\text { Abomasum }\end{array}$ & $\begin{array}{l}2 \cdot 3 \\
0\end{array}$ \\
\hline $\begin{array}{l}\mathbf{3}^{\mathbf{A}} \\
\mathbf{3}^{\mathbf{A}^{\prime}}\end{array}$ & $\begin{array}{l}\text { Omasum } \\
\text { Omasum }\end{array}$ & $\begin{array}{l}0 \\
0\end{array}$ \\
\hline
\end{tabular}

No aureomycin assays were carried out with calf IA. The caecum of calf $2 \mathrm{~A}$ contained no aureomycin.

significant differences between rumen contents of aureomycin-fed and control calves. The oldest aureomycin-fed calf $(3 \mathrm{~A})$ had the most diverse microflora. A noteworthy feature was the unexpected prevalence of Gram-positive rods, probably lactobacilli. The viable saccharolytic counts (Table 4 ) showed a gradual increase in the ratio of

Table 4. Effect of aureomycin on counts of viable rumen bacteria of calves

\begin{tabular}{|c|c|c|c|c|c|}
\hline \multirow{4}{*}{$\begin{array}{l}\text { Calf no. } \\
\text { o }\end{array}$} & \multicolumn{3}{|c|}{$\begin{array}{l}\text { Gram-positive cocci ( + some } \\
\text { coliform bacteria) fermenting }\end{array}$} & \multirow{3}{*}{$\begin{array}{l}\text { Gram-positive rods } \\
\text { (microaerophilic) } \\
\text { in high dilution }\end{array}$} & \multirow{3}{*}{$\begin{array}{c}\text { Gram-negative } \\
\text { cocci (anaerobic) } \\
\text { obtained in } \\
\text { pure culture }\end{array}$} \\
\hline & Cellobiose & $\begin{array}{l}\text { Cellobiose in } \\
\text { the presence of } \\
\text { crystal violet* }\end{array}$ & Mannitol & & \\
\hline & \multicolumn{3}{|c|}{ (106 $/ \mathrm{g}$ rumen contents) } & & \\
\hline & $3^{87}$ & - & 474 & - & - \\
\hline IA & $8 \cdot 8$ & - & 10.6 & - & + \\
\hline $\mathbf{I} \mathbf{A}^{\prime}$ & $7 \cdot 2$ & $9 \cdot 4$ & $5 \cdot 8$ & - & - \\
\hline${ }_{\mathrm{I}} \mathrm{C}$ & 0.17 & - & 0.12 & $+++\left(10^{\%} / \mathrm{g}\right)$ & + \\
\hline $2 \mathrm{~A}$ & $\begin{array}{l}104 \\
8 \cdot 6\end{array}$ & $\begin{array}{r}34 \\
7\end{array}$ & $\begin{array}{l}3 \cdot 6 \\
5 \cdot I\end{array}$ & - & - \\
\hline${ }_{2} \mathrm{C}$ & 29 & $\mathrm{I} \cdot 8$ & 3.0 & - & - \\
\hline $\begin{array}{l}3 \mathrm{~A} \\
3 \mathrm{~A}^{\prime}\end{array}$ & $\begin{array}{l}90 \\
52\end{array}$ & $\begin{array}{r}4 \cdot 8 \\
27 \cdot 5\end{array}$ & $\begin{array}{l}2 \cdot 4 \\
0.27\end{array}$ & ++ & - \\
\hline${ }_{3} \mathrm{C}$ & $5^{88}$ & 212 & $5 \cdot 7$ & - & - \\
\hline
\end{tabular}

* Usually $0.002 \%$ was added to the agar in the hope of suppressing some Gram-positive cocci.

cellobiose-fermenting to mannitol-fermenting bacteria with increasing age of the animal. The very small streptococcal count in the first control corresponded to very acid conditions in the rumen (Table 2 , calf $I$ C). The count of aciduric lactobacilli was, however, very great in this instance $\left(c .10^{9} / \mathrm{g}\right)$. An interesting obligate anaerobic lactobacillus(?) was isolated in pure culture in this experiment and will be described in detail in a later paper. Lactobacilli (all aureomycin-sensitive) were also isolated from 
other animals, both aureomycin-fed and controls. These, however, were facultative anaerobes. Of twenty-two streptococcal isolates tested, only two (from calf I $A^{\prime}$ ) proved to be really resistant in pure culture to a concentration of aureomycin of I6 $\mu \mathrm{g} / \mathrm{ml}$. Most were inhibited at $4 \mu \mathrm{g} / \mathrm{ml}$.

Ciliate protozoa in the rumen. The picture here was confused owing to the presence in the same animal house of an adult rumen-fistulated animal, possessing a most dense and varied rumen microfauna. The second set of aureomycin-fed calves ( $2 \mathrm{~A}$ and $2 A^{\prime}$ ) was kept in a pen adjacent to this adult, and when killed (at about 8 weeks of age) had a very similar rumen microfauna comprising the following living ciliates: several species of Eudiplodinium and of Entodinium, all plentiful; Isotricha present but scarce; Dasytricha absent as in the adult animal. It was noteworthy that the 'mediumsized' micro-organisms (i.e. those much larger than most of the rumen eubacteria and much smaller than ciliate protozoa) that are found in the rumens of adult cattle (Baker, 1942) were absent. The third set of aureomycin-fed animals ( $3 \mathrm{~A}$ and ${ }_{3} \mathrm{~A}^{\prime}$ ), which were two pens away from the adult in the other direction, had an extraordinarily rich rumen population of Entodinium, mostly starch-ingesting. Isotricha was again scarce, but Eudiplodinium was absent. The three controls, which were in one pen on the opposite side of the animal-house, were all completely devoid of ciliates in their rumens when killed.

\section{DISCUSSION}

It appears from these results that there was no direct inhibitory effect of aureomycin, taken by mouth, upon the calf's rumen bacteria at any time, since ( $\mathrm{r}$ ) no aureomycin could ever be detected in the rumen, possibly because, being administered in a gruel, it passed direct to the omasum and abomasum via the oesophageal groove, and furthermore, X-ray studies carried out with young calves at this Institute (Benzie, 1953) have shown that the backflow to the rumen from the abomasum, although detectable some $2 \mathrm{~h}$ after feeding, involves only a small fraction of the abomasum contents; (2) the normal adult rumen microflora and microfauna seemed to become established at an earlier age in the aureomycin-fed animals than in the controls. A very simple reason for the second fact is worth considering, namely that with the aureomycin-fed animals the rumen contents more quickly reached a bulk and $\mathrm{pH}(>6)$ suitable for large-scale anaerobic bacterial action. Granting this, the aureomycin may be said to act indirectly on the rumen bacteria, by causing the animal to become a better host for them. Thus the problem seems to be primarily a physiological, rather than a microbiological one, although of course an antibacterial action in the small intestine is not excluded. It is perhaps significant that a detectable concentration of aureomycin was maintained in the abomasum (where bacterial action is not in evidence), the acid $\mathrm{pH}$ of which does in fact correspond to the point of maximum chemical stability of aureomycin, particularly in presence of proteins. On the other hand, no aureomycin was found in the caecum, the $\mathrm{pH}$ of which is on the alkaline side, so it may be concluded that the antibiotic is mostly absorbed somewhere in the true digestive tract before the caecum is reached, and the remainder, if any, destroyed in the caecum.

A further apparent difference between the aureomycin-fed and control calves was that only the former developed a ciliate population in the rumen as soon as the rumen 
$\mathrm{pH}$ ceased to be too acid for their continued existence, i.e. ceased to be below 6 . Too much emphasis is not laid, however, on this finding since the pens in which the aureomycin-fed animals were kept were certainly nearer to the solitary adult cow kept in the same animal house than the pen containing the control calves. What is striking is that a complete ciliate microfauna can be established at a very early age ( 8 weeks) as soon as the rumen $\mathrm{pH}$ of the calf becomes favourable. If feeding of aureomycin always causes this point to be reached much sooner than usual, then the beneficial effect of the antibiotic would become apparent at an early age but would cease later, as seems to be the case, when the adult rumen microflora and microfauna become properly established.

\section{SUMMARY}

I. Aureomycin hydrochloride $(40-60 \mathrm{mg}$ ) was fed daily in gruel to three sets of two calves from about the I2th day to approximately the 5th, 8th and I2th week of age respectively, when the calves were killed together with a control calf of the same age. The contents of their paunches and abomasums were then examined.

2. The aureomycin-fed calves had larger and less acid rumen contents than the controls, and reached a rumen $\mathrm{pH}(>6)$ suitable for intensive rumen bacterial and protozoan action at a much earlier age.

3. Aureomycin could never be detected in the rumen, although it was indisputably present in the abomasum, usually at a concentration of $2-5 \mu \mathrm{g} / \mathrm{g}$ ingesta. The antibiotic could not be detected in the caecum, and only traces were present in the omasum.

4. There was little difference between the aureomycin-fed and control calves in the final development of a typical rumen viable streptococcal population.

5. It is concluded that aureomycin taken by mouth does not act directly on the rumen micro-organisms.

Our best thanks are due to Dr A. T. Mennie, Medical Director, Lederle Laboratories Division, Cyanamid Products Ltd., Bush House, London, W.C. 2, for arranging for a supply of pure aureomycin hydrochloride to be sent to this Institute for these experiments. We are also greatly indebted to Mr W. Thomson, Mr E. L. B. Haskew and the staff of the Metabolic Department of this Institute for the care taken in purchasing, feeding and rearing the calves, and to our colleague, Dr J. Christine Appleby, for demonstrating the 'pad-plate' method of aureomycin assay to us.

Baker, F. (1942). Nature, Lond., I49, 220.

\section{REFERENCES}

Benzie, D. (1953). Private communication.

Gale, E. F. \& Folkes, J. P. (1953). Biochem. F. 53, 493.

Grady, J. E. \& Williams, W. L. (1953). Antibiot. Chemother. 3, 58.

Heald, P. J., Krogh, N., Mann, S. O., Appleby, J. C., Masson, F. M. \& Oxford, A. E. (1953). F. gen. Microbiol. 9, 207.

Hungate, R. E., Dougherty, R. W., Bryant, M. P. \& Cello, R. M. (1952). Cornell Vet. 42, 423.

Knodt, C. B. (1953). Antibiot. Chemother. 3, 442.

MacPherson, M. J. (1953). F. Path. Bact. 66, 95.

Mann, S. O., Masson, F. M. \& Oxford, A. E. (I954). F. gen. Microbiol. 10, 142.

Paine, 'T. F. Jr., Collins, H. S. \& Finland, M. (1948). F. Bact. 56, 489.

Schneierson, S. S. \& Toharsky, B. (I 949). F. Bact. 57, 483 .

Sugden, B. \& Oxford, A. E. (1952). F. gen. Microbiol. 7, 145 . 